\title{
Low-cost air levitation laboratory stand using MATLAB/Simulink and Arduino
}

\author{
Ewelina Chołodowicz, Przemysław Orłowski \\ Zachodniopomorski Uniwersytet Technologiczny, Wydział Elektryczny, Katedra Sterowania i Pomiarów, ul. Sikorskiego 37, 70-313 Szczecin, Poland
}

\begin{abstract}
In this paper, low cost air levitation project is presented as a teaching tool for control engineering. Air levitation control system is built as a classroom demonstration device and laboratory stand. The laboratory stand provides a new plant to control for students of control engineering. It is comprised of Arduino Mega 2560, plexiglass, metal elements and 3D printed parts.
\end{abstract}

\section{Introduction}

Student access to laboratory experiments is critical in education because engineering is a practical discipline. Universities give huge financial support in providing traditional laboratory stands for physics, mathematics, robotics and other fields of science. Advanced learning technologies have emerged to enhance learning, support new inventions and improve interest in engineering studies. Laboratories are a common part of engineering education, therefore more and more universities began to build more low-cost laboratory stands. Research shows that hands-on laboratory experiments help students understand and apply course material $[1,2]$. A classroom demonstration device is always very helpful in teaching engineering courses particularly for control engineering and robotics. With the rise in popularity of using low-cost hardware there are new alternatives to teach control engineering in practice. Some affordable laboratory devices for engineering education have already been developed [3-11], such as the Mobile Studio IOBoard used in introductory circuits courses [6]. One of the devices which are able to teach a wide range of algorithms used in control engineering are levitation laboratory stands. Levitation project systems have long been used in control system laboratories [12-14]. Levitation is a process in which an object is suspended against gravity by a physical force. Many methods can be used as the levitating medium, including magnetic repulsion, viscous liquids, sound waves and air currents. Interesting example of levitation is based on air flow. Air levitation uses an air stream provided by a fan to obtain the levitating force on a ping-pong ball. This phenomenon stems from Bernoulli principle [15]. Controlling the ping-pong ball is a challenging task and it requires a control

\section{Autor korespondujący:}

Ewelina Chołodowicz, cholodowicz.ewelina@gmail.com

\section{Artykuł recenzowany}

nadesłany 06.11.2017 r., przyjęty do druku 12.12.2017 r. system. The air levitation control system is considered as an interesting and impressive device for educational purpose. These projects are appropriate for lab stations, but they require custom construction of the stand and dissipate considerable power. This kind of projects are good teaching tools and help to teach control theory. In addition, the system is simple and small that is very convenient to be carried from class to class. Moreover, it requires a little space and little amount of power. This kind of laboratory stand can be an environment for implementing a variety of controllers, for instance: proportional-integral-derivative controller, hybrid controller, predictive controller, fuzzy logic controller and others which are used for nonlinear systems.

In this paper, portable and affordable laboratory stand is designed to support the accompanying curriculum for the introductory controls course in control engineering at the Faculty of Electrical Engineering at West Pomeranian University of Technology in Szczecin. In particular, a description of the air levitation laboratory stand is presented and some example with identification, optimization and proportional-integral-derivative controller. The objective is to design low-cost stand with educational functionality. The laboratory stand uses new technology tools: Arduino Mega 2560 and MATLAB/Simulink. This stand increases the accessibility of the controls laboratory experience for students, can result in improvement of the level of teaching and is a good teaching tool for general engineering students. The stand design consists of Arduino Mega 2560, an axial box fan usually used for cooling electrical equipment, sonar sensor and the various circuits to drive the motor, to measure speed, and perform identification. The objective of this system is to enable endto-end student implementation of a variety of control systems. This includes implementation of sophisticated system identification, design of control algorithms, and experimental verification. One of the primary objectives in designing the air levitation lab stand was to ensure that it could be easily adopted by any student, regardless of how they want to learn. A primary objective of the air levitation stand is to provide students with a testbed on which they can develop and empirically verify control algorithms. 


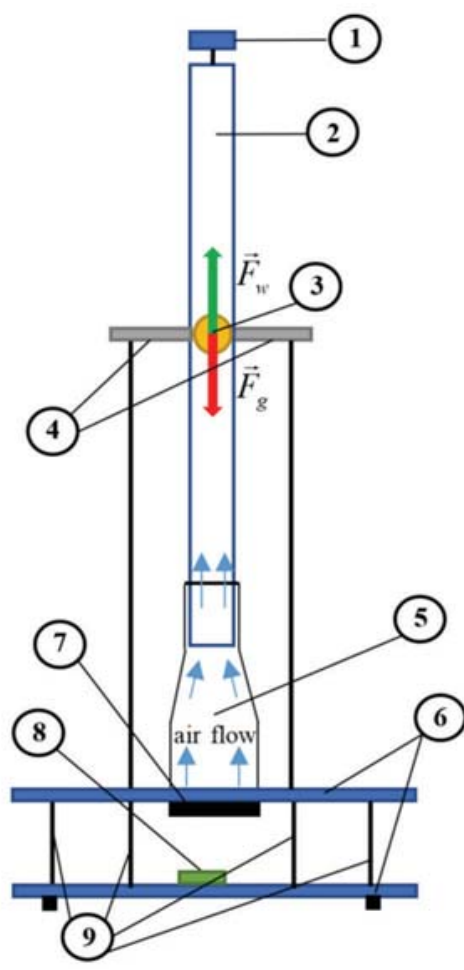

Fig. 1. Scheme of air levitation laboratory stand

Rys. 1. Schemat stanowiska laboratoryjnego do realizacji zadania lewitacji powietrznej

\section{Physical design and characteristics}

The air levitation laboratory stand presented in this paper has a minimalist design in order to be cheap and easy to replicate, rebuild and repair. The system has been built using the following components presented in fig.1: 1) an ultrasonic sensor, 2) a plexiglass tube, 3) a ping-pong ball, 4) a wooden plate with a hole 5) a $3 \mathrm{D}$ printed cylinder, 6) plexiglass plates, 7 ) a fan, 8) a control unit and 9) threaded rods.

Figure 2 shows an assembled air levitation system. In order to achieve an air stream capable of levitating a ping pong ball, a fan with high air volume and static pressure was required. Several fan styles were considered for this project including a centrifugal and a axial fan. The final source of air is an DC axial fan with radius of $4.5 \mathrm{~cm}$. It is inserted into a hole in a horizontal sheet of plexiglass, blowing upwards. 3D printed element in the shape of roller and cone (black element in the bottom of the pipe) is to concentrate the air flow directly from the fan in the bottom. The fan is controlled by Pulse-Width Modulation (PWM) signal. The Low-Voltage H-Bridge Driver DRV883x can supply up to $1.8 \mathrm{~A}$ of output current. It operates on a motor power supply voltage from $0 \mathrm{~V}$ to $11 \mathrm{~V}$. Once the fan is chosen, a proper outlet port and connector is needed. In particular, the system is designed with Arduino self-designed shield. The main controller of the system is Arduino Mega 2560.

To measure the distance of the ping-pong ball from the device, both sonar and infrared sensors were tested. Tested Infra-Red (IR) Sharp distance sensors. have inadequate detection ranges for the ball levitation task, with a deadband of about 10-20 cm for measurement up to $100 \mathrm{~cm}$, while sonar offered detection at distances from $2 \mathrm{~cm}$ to $200 \mathrm{~cm}$ with a ranging accuracy that can reach up to $3 \mathrm{~mm}$. Other components of the system are plexiglass, metal bars, leds, buttons and metal holder for sensor, which provides stable position over the pipe to allow air flow.

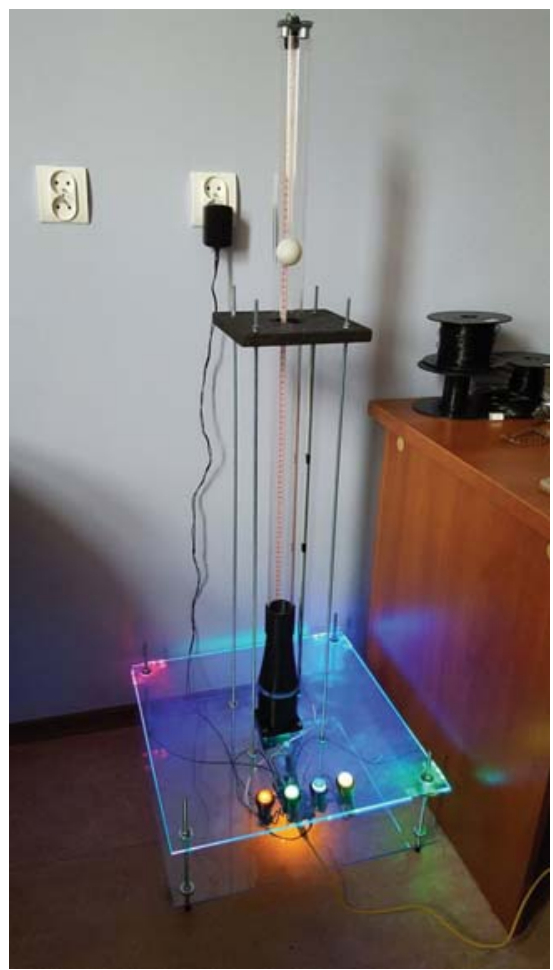

Fig. 2. An assembled air levitation system. The controller senses the position of the object with ultrasonic sensor and drives the current in the fan to maintain levitation

Rys. 2. Zbudowane stanowisko laboratoryjne do lewitacji powietrznej. Sterownik wyznacza położenie obiektu za pomocą czujnika ultradźwiękowego i wypracowuje sygnał sterujący do wentylatora, tak aby obiekt lewitował w powietrzu

Diagram of the air levitation system is shown in fig. 3. In this system, the position of the levitated object is measured by a ultrasonic sensor. The output voltage of the motor drives the input of a low-cost motor drive, which produces a pulsewidth modulated signal for fan control. This PWM signal controls air flow in the pipe.

\section{System analysis and control system}

The dynamic equation for air levitation system is obtained on the basis of the Newton's second law of motion. The aerodynamic lift has been studied in [16-18]. Air levitation is system

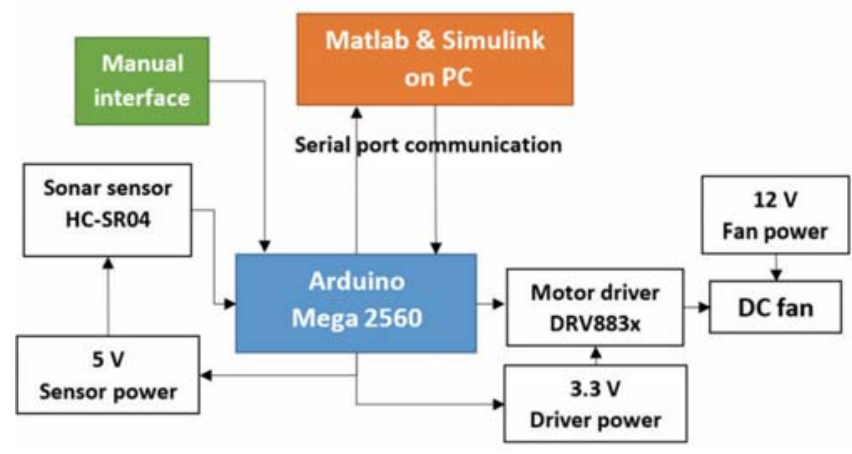

Fig. 3. Diagram of air levitation system. The position of the levitated object is sensed by the ultrasonic sensor: HC-SR04. The output voltage of the sensor drives the input of the fan. The controller produces a PWM signal to the fan which controls the air flow Rys. 3. Schemat systemu lewitacji powietrznej. Pozycja obiektu lewitującego jest mierzona przez czujnik ultradźwiękowy: HC-SR04. Napięcie wyjściowe czujnika wpływa na wartość sygnału sterującego wentylatorem. Sterownik wytwarza sygnał PWM dla wentylatora, który z kolei steruje przepływem powietrza 
consists of a ping-pong ball of mass $m$, which is placed underneath the fan at distance $x$ in plexiglass. The current flowing into the fan will generate air flow force to attract the ball bearing. The net force between the air flow force and gravitational force will induce an up or down motion of the ball bearing. The ultrasonic sensor measures the distance between the bottom of the pipe and the ball. In this way, sensor provides the information about position of the ball. The system's dynamic equations can be obtained as:

$$
m x=-m g+F_{w}(\omega, c, \tau, x)
$$

where: $F_{w}$ - air flow force (function), $\omega$ - speed of the fan, $\tau$ delay associated with the moment of inertia of a fan, $c$ - fan coefficient (shape, number of blades and radius), $m$ - mass of the ball, $g$ - gravitational acceleration, $x$ - distance between ultrasonic sensor and ball.

The air levitation system is an unstable nonlinear system. The air flow force is a function of three parameters: speed of the fan, fan coefficient (shapes, blades and radius) and delay associated with the moment of inertia. As control systems are concerned, this system is with one input and one output (SISO). The input signal is the air flow force generated by fan and output is the distance between the sensor and the top of the ball. The system dynamic equations are nonlinear. This is due to nonlinear description of the air stream, which subjects to the Bernoulli's equation [19]. This equation makes an interesting prediction about the relationship between the pressure and the speed of a moving ideal fluid:

$$
p_{1}+\frac{1}{2} \rho v_{1}^{2}+\rho q h_{1}=p_{2}+\frac{1}{2} \rho v_{2}^{2}+\rho q h_{2}
$$

where: $p_{1}, p_{2}$ - static pressure of air at the cross section (pressure energy), $\rho$ - density of the flowing air, $h_{1}, h_{2}$ - distance between ultrasonic sensor and ball, $v_{1}, v_{2}$ - mean velocity of fluid flow at the cross section

The air levitation works on Bernoulli principle: the faster air moves, the lower static pressure is, and the higher is dynamic pressure. In the experiments, one side of the ping balls is in contact with a low pressure (due to the airflow) which creates a pressure gradient, the other side of the ball is in contact with a higher pressure which results in the ball being pushed towards the region of low pressure. Placing ball in the tube allow to achieve higher heights but the Bernoulli principle still works. This is because the tube accumulates the air increasing the speed around the ball and allow the ball to go higher. As air is blown out from the fan, air flow at high speed and this creates a region of low pressure across the top of the pipe. The still air around the ball is at a higher pressure and pushes on the ball and causes it to stay in the air.

\section{Experimental example}

In this section the results of the real-time research are presented. The objective of the experiment is to levitate a ping pong ball in a transparent tube. An aerodynamic force is produced by an axial fan and applied to a ping pong ball in a plexiglass tube. The ball position in the tube is measured with a distance sensor. A proportional-integral-derivative controller (PID) is designed in Simulink and implemented on Arduino Mega 2560. System identification and optimization techniques are used to control this nonlinear system. The main purpose of this section is to show the identification and the optimization results for the designed control system. Due to the complexity of the system, linear model is obtained. Determining the response of a system at an operating point is a critical step in system and controller design. To find a linear model of the designed system, linearization of air levitation is calculated. The operating point has the following values:

$$
\begin{gathered}
x_{0}=45 \mathrm{~cm} \\
u_{0}=230
\end{gathered}
$$

where $u_{0}$ is a PWM output signal, which ranges from 0 to 255 and represents the value of the PWM duty cycle. The point (3) is chosen because it provides stable behavior of the system: the ball is able to float slightly in the center of the pipe for a few seconds. In fact, operating points with a strongly nonlinear character are not suitable for linearization. Next, an offset in model output and model input have to be included:

$$
\begin{aligned}
& \widetilde{u}=u-u_{0} \\
& \widetilde{x}=x-x_{0}
\end{aligned}
$$

Input-output data from real-time experiment is used to apply least-squares method to the process of identification. First, the input signal in fig. 4 is generated.

In the next step of identification process, having input and output data from the same experiment allows conducting model identification. However, before that, the proper model structure is selected. For discrete-time model estimation, transfer function with one pole and without zeros is chosen. This model is selected by an empirical method - it shows relatively good fit to the process at the smallest possible order of the model. Nonetheless, higher-order models has been also tested. In this way, the discrete-time transfer function is obtained in the following form:

$$
G\left(z^{-1}\right)=\frac{-0.1787 z^{-1}}{1-z^{-1}}
$$

The identification provides percent fit to estimation data equals $77.32 \%$. The model identified around the operating point is linear and has a sample time of $0.2 \mathrm{~s}$.

Figure 5 depicts data collected directly from the designed real-time system and the response of the calculated model described by (5).

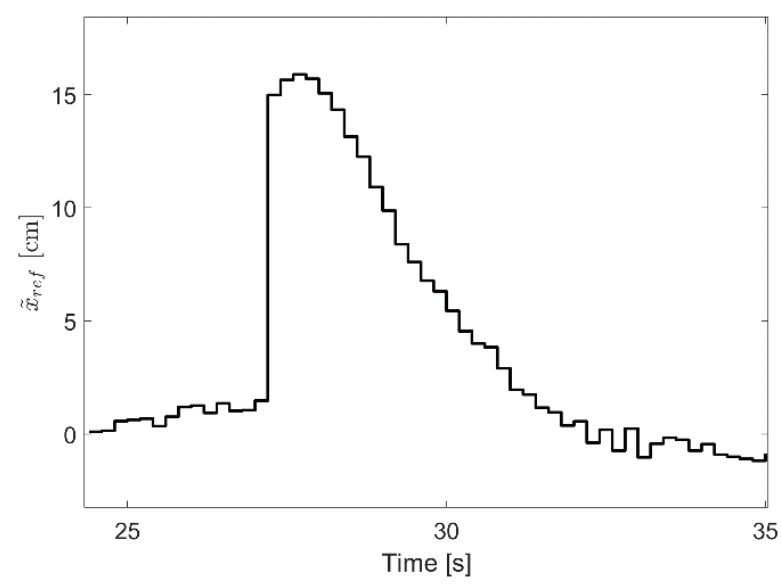

Fig. 4. Input signal for the identification experiment Rys. 4. Zadany sygnał wejściowy na potrzeby eksperymentu identyfikacyjnego 
It is important to highlight that, verification of new model is necessary to fulfill the identification task. It examines the behavior of the model with a different input signal. This step is crucial because it shows the estimation error, decides the correctness of the model and its usefulness.

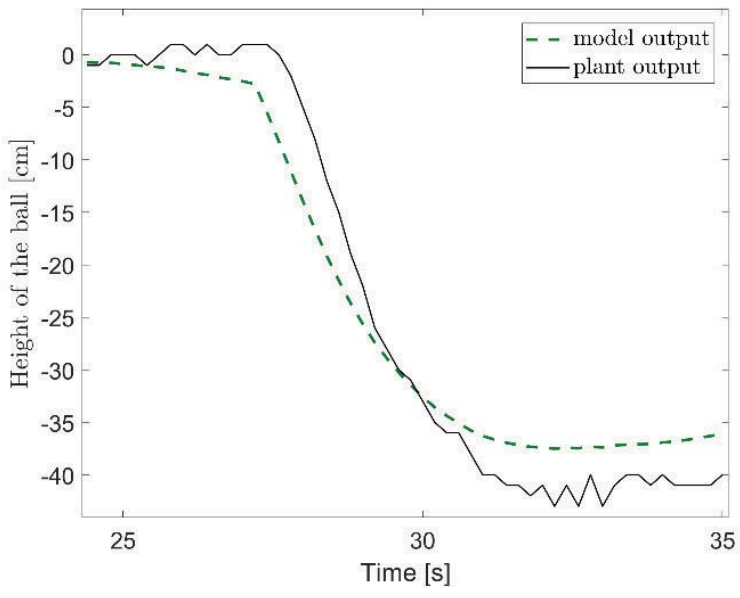

Fig. 5. Model output and plant output - identification

Rys. 5. Sygnał wyjściowy modelu i obiektu rzeczywistego - identyfikacja

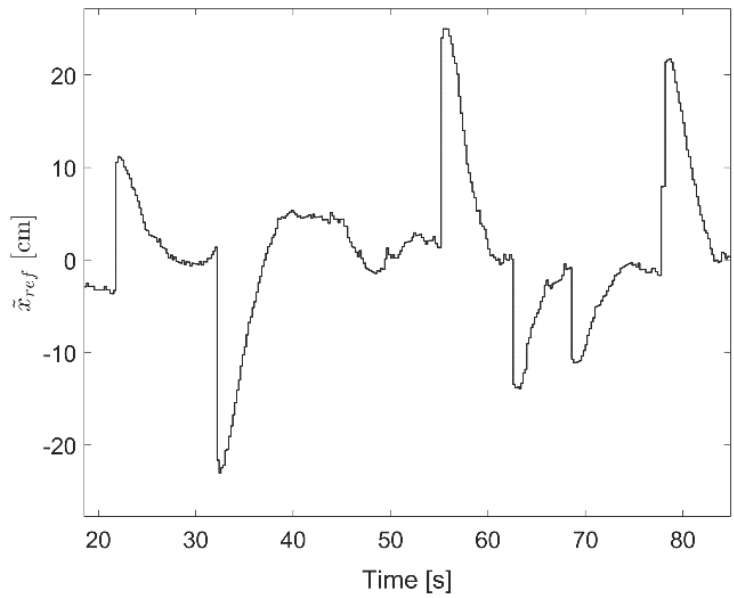

Fig. 6. Input signal for the verification of the evaluated model in the process of identification

Rys. 6. Sygnał wejściowy do weryfikacji wyznaczonego modelu w procesie identyfikacji

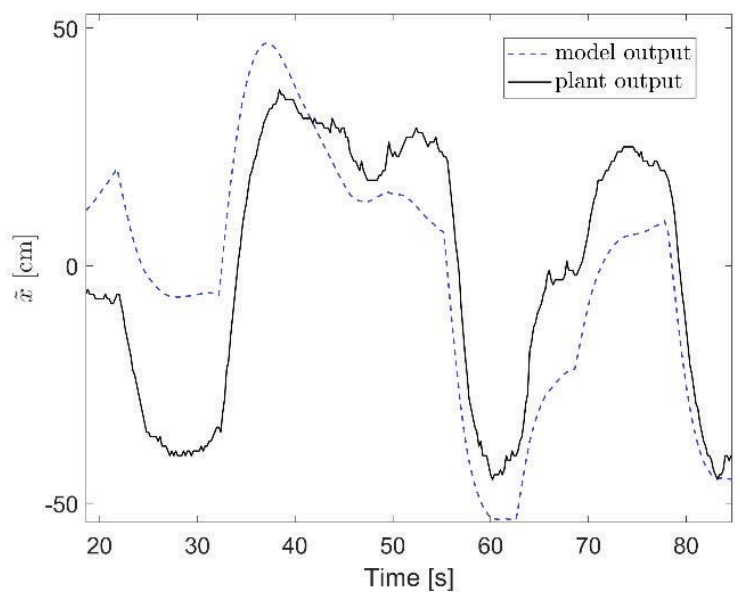

Fig. 7. Model output and plant output - verification

Rys. 7. Sygnał wyjściowy modelu i obiektu rzeczywistego - weryfikacja
There is a input signal for verification in fig. 6. and results are presented in fig. 7 . It can be seen, that the obtained model has similar output signal as the real-time system. Thus, the calculated model is correct and can be used in the next task: optimization.

In order to tune parameters of PID controller, the optimization model is needed. First, the optimization task is explained.

In fig. 8 the optimization model is presented where $k_{1}, k_{2}$, $k_{3}$ are all non-negative coefficients for the proportional, integral, and derivative terms. This is an example of model for students which can be used as an introduction to control systems and optimization. In the optimization model, the error is presented as following equation:

$$
\widetilde{e}=\widetilde{x}_{r e f}-\widetilde{x}
$$

where $\tilde{\boldsymbol{x}}_{\text {ref }}$ is the set point and is an actual reading from the sensor and $\tilde{x}$ is the process value (current position of the ball).

By tuning the three parameters of the model, a PID controller can deal with specific process requirements. Consider, the problem of finding the optimal values of the parameters of a dynamic system in fig. 8. In the case of air levitation system cost function can be defined by the following relations:

$$
J=\sum_{k}\left[\widetilde{x}_{r e f}(k)-\widetilde{x}(k)\right]^{2}
$$

The optimization problem can be defined in the following form:

$$
\min _{k} J
$$

where optimization variables and constraints are dependent on the controller structure:

$$
\mathbf{k}=\left[k_{1}, k_{2}, k_{3}\right], \quad k_{1} \geq 0, \quad k_{2} \geq 0, \quad k_{3} \geq 0
$$

Tuning of the control system is based on the genetic algorithm optimization with default parameters: population size: 50 , initial population range: $[-10 ; 10]$ and crossover fraction: 0.8 . In the result of optimization process, the PID coefficients have following values:

$$
k_{1}=5.6, \quad k_{2}=0.0004, \quad k_{3}=0.0025
$$

The primary software package is MATLAB and Simulink. A useful set of MATLAB/Simulink and Arduino Support

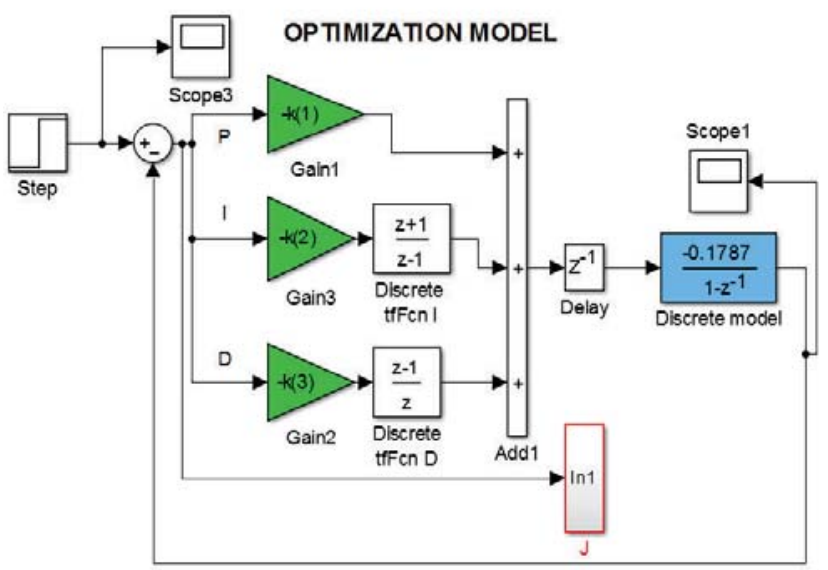

Fig. 8. Model used for the optimization problem described by (8) Rys. 8. Model zastosowany do problemu optymalizacji opisanego zależnością (8) 
for Simulink package tools provides communications blocks. These libraries are very helpful in setting up built in functions. There are also several predefined functions in MATLAB and Simulink that make it easier for students to develop code. Students can manually tune a PID controller in simulation

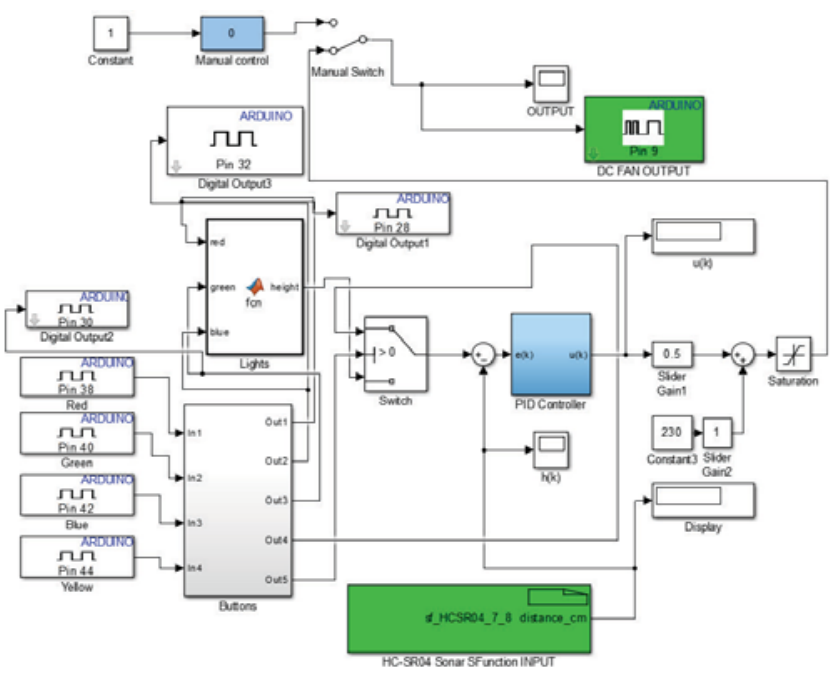

Fig. 9. Control loop of air levitation control in Simulink Rys. 9. Pętla sterowania obiektem lewitacji powietrznej w programie Simulink

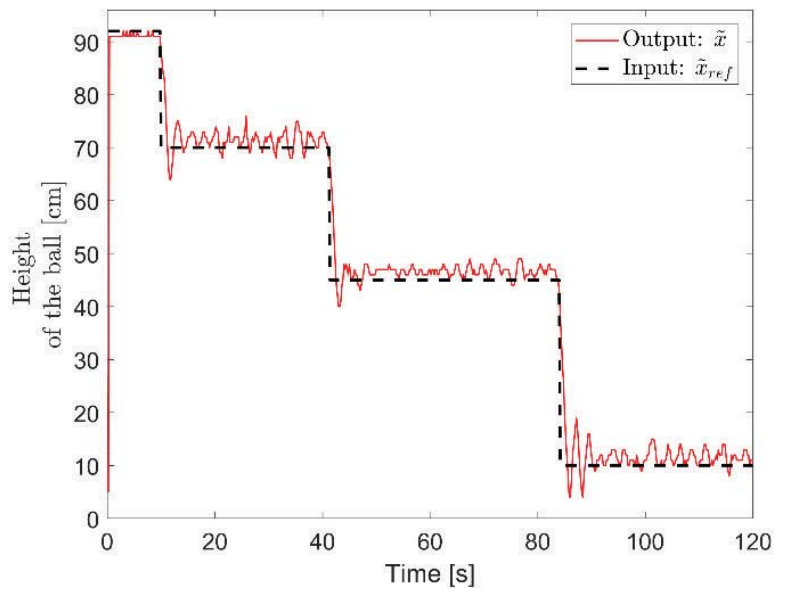

Fig. 10. Reference value of height and real-time air levitation system response

Rys. 10. Wartość referencyjna wysokości i odpowiedź systemu lewitacji w czasie rzeczywistym

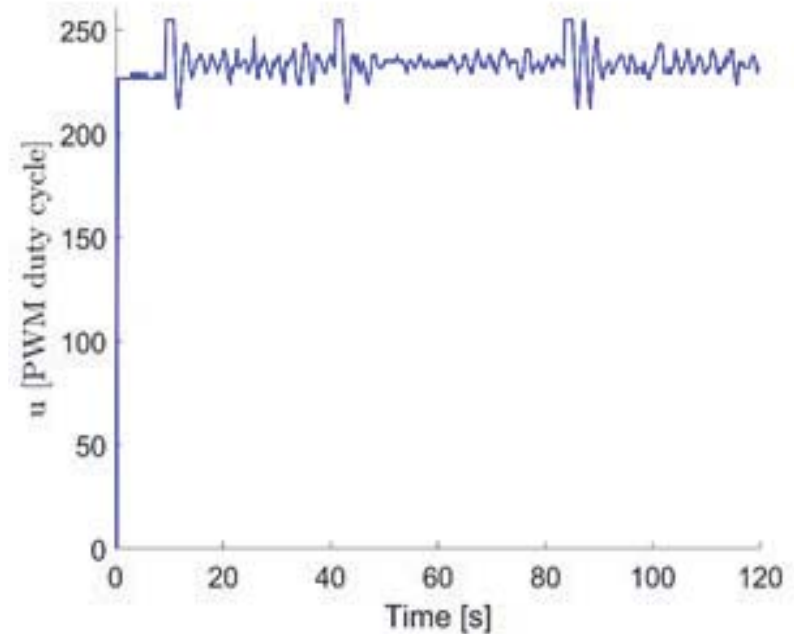

Fig. 11. Input signal of real-time air levitation system

Rys. 11. Sygnał wejściowy systemu lewitacji w czasie rzeczywistym before verifying its performance in real time system. All of the models are run in Simulink's external mode or are deployed to hardware via USB connection and work standalone. External mode allows the data to be viewed while the simulation is running. When the Simulink model is run in External mode, data can collected and viewed as the code runs via scopes or other sinks provided in Simulink. The models were built and tested in MATLAB Release 2014b. An S-function builder block is used to generate the signal from ultrasonic sensor. Communication blocks from Arduino Support package for Simulink are used for manual interface and fan control. The real-time closed loop control system is presented in fig. 9.

The designed control system uses PID to keep the ball in the reference position. To observe the performance on a physical air levitation stand, the obtained coefficients (10) are used. The reference value and output of the air levitation real-time system are shown in fig. 10.

It can be seen in fig. 10 that, values from the sonar sensor are with some noise. Despite of this, the ping-pong ball reaches the reference position with small oscillations. The input signal of the air levitation system is presented in fig. 11.

Output of the PID controller is limited: from 212 to 255 because for this values of speed, ping-pong ball is able to achieve different positions. The value of 229.5 corresponds to position in which the ball is in the center of the tube.

\section{Conclusions}

An intuitive interface and easy programming environment in Simulink is proper for control engineer who do not have an advanced knowledge in programming but in control theory. This low-cost air suspension stand provides students with a plant for implementing control algorithms. Moreover, the ultrasonic sensor and a PC fan is an inexpensive and adequate solution to make the laboratory stand replicable and mobile. The total cost of the laboratory stand provided to the students is under $\$ 80$. Meeting these goal made it possible to let the students deeper their knowledge about control systems using real-time hardware and software. These components enabled students to work providing all the capabilities of a traditional laboratory. The results of the work can be seen in the video [20]. The great success of this stand has trigger improvements in other laboratories. In addition, there are also plans to use the designed laboratory stand as low-cost platform for research.

\section{References}

1. Ma J., Nickerson J.V., Hands-on, simulated, and remote laboratories: A comparative literature review, "ACM Computing Surveys", Vol. 38, No. 3, 2006,

DOI: $10.1145 / 1132960.1132961$.

2. Feisel L.D., Rosa A.J., The role of the laboratory in undergraduate engineering education. Journal of Engineering Education, Vol. 94, Iss. 1, 2005, 121-130,

DOI: $10.1002 /$ j.2168-9830.2005.tb00833.x.

3. Wojtulewicz A., Chaber P., Ławryńczuk M., Multiple-input multiple-output laboratory stand for process control education. [in:] 21st International Conference on Methods and Models in Automation and Robotics (MMAR), 2016, 466-471.

4. Artigas J.I., Barragán L.A., Llorente S., Marco A., Lucía O., Low-Cost Magnetic Levitation System for Electronics Learning, 4th IEEE International Conference on E-Learning in Industrial Electronics, 2010, 55-60, DOI: 10.1109/ICELIE.2010.5669845. 
5. Knapkiewicz P., Melnyk M., Teslyuk V., Dziuban J., Lobur M., Szermer M., Mechatronic laboratory stand. [in:] XII International Conference on Perspective Technologies and Methods in MEMS Design (MEMSTECH), 2016, 31-33,

DOI: 10.1109/MEMSTECH.2016.7507514.

6. Millard D., Chouikha M., Berry F., Improving student intuition via Rensselaer's new mobile studio pedagogy. [in:] Proceedings of the 114th Annual ASEE Conference and Exposition, Honolulu, HI, 2007.

7. Czyba R., Niezabitowski M., Sikora S., Construction of laboratory stand and regulation in ABS car system. [in:] 17th International Carpathian Control Conference (ICCC), 2016 140-145,

DOI: 10.1109/CarpathianCC.2016.7501082.

8. Reck R.M., Sreenivas R.S., Developing an Affordable and Portable Control Systems Laboratory Kit with a Raspberry Pi. "Electronics", 5(3), 2016, 36,

DOI: $10.3390 /$ electronics5030036.

9. Aktan B., Bohus C.A., Crowl L.A., Shor M.H., Distance learning applied to control engineering laboratories. IEEE Transactions on Education, Vol. 39, Iss. 3, 1996, 320-326, DOI: $10.1109 / 13.538754$.

10. Dixon W.E., Dawson D.M., Costic B.T., Queiroz M.S.D., A MATLAB-based control systems laboratory experience for undergraduate students: Toward standardization and shared resources. "IEEE Transactions on Education", Vol. 45, Iss. 3, 2002, 218-226,

DOI: 10.1109/TE.2002.1024613.

11. Gunasekaran M., Potluri R., Low-Cost Undergraduate Control Systems Experiments Using Microcontroller-Based Control of a DC Motor. "IEEE Transactions on Education", Vol. 55, Iss. 4, 2012, 508-516,

DOI: $10.1109 /$ TE.2012.2192441.

12. Lilienkamp K.A., Low-cost magnetic levitation project kits for teaching feedback system design. Proceedings of the 2004 American Control Conference, IEEE, Vol. 2, 13081313, 2004.
13. Lundberg K.H.; Lilienkamp K.A.; Marsden G., Low-cost magnetic levitation project kits. "IEEE Control Systems", Vol. 24, Iss. 5, 2004, 65-69,

DOI: $10.1109 / \mathrm{MCS} .2004 .1337863$.

14. Glehn G., Appunn R., Hameyer K., A small scale magnetically levitated train for project-based laboratory education. "Archives of Electrical Engineering", Vol. 64, Nr 4, 2015, 617-628,

DOI: $10.1515 /$ aee-2015-0046.

15. Waltham C., Bendall S., Kotlicki A., Bernoulli levitation. "American Journal of Physics", Vol. 71, No. 2, 2003, 176179 ,

DOI: $10.1119 / 1.1524162$.

16. Timmerman P., van der Weelea J.P., On the rise and fall of a ball with linear or quadratic drag. "American Journal of Physics", Vol. 67, Iss. 6, 1999, 538-546, DOI: $10.1119 / 1.19320$.

17. Jernigan S.R., Fahmy Y., Buckner G.D., Implementing a Remote Laboratory Experience Into a Joint Engineering Degree Program: Aerodynamic Levitation of a Beach Ball. "IEEE Transactions on Education", Vol. 52, Iss. 2, 2009, 205-213,

DOI: $10.1109 /$ TE.2008.924217.

18. Escaño J.M., Ortega M.G., Rubio F.R., Position control of a pneumatic levitation system. Proceedings of the 10th IEEE International Conference on Emerging Technologies and Factory Automation, Catania, Italy, 19-22 September 2006 , DOI: 10.1109/ETFA.2005.1612568.

19. Qin R., Duan C., The principle and applications of Bernoulli equation. Journal of Physics: Conference Series (Vol. 916, No. 1, p. 012038), 2017, IOP Publishing, DOI: $10.1088 / 1742-6596 / 916 / 1 / 012038$.

20. Chołodowicz E., Air levitation of ping-pong PID and inverse model control in MATLAB/Simulink, [on-line] https://www.youtube.com/watch?v=-ym_oQwLcf0, available 1.09.2017. z wykorzystaniem Arduino oraz pakietu oprogramowania MATLAB/Simulink

\author{
Streszczenie: w pracy przedstawiono projekt stanowiska laboratoryjnego do lewitacji powietrznej. \\ Obiekt został zaprojektowany oraz zbudowany dla celów edukacyjnych oraz naukowych w dziedzinie \\ szeroko pojętej automatyki oraz teorii sterowania. Ukazane w pracy stanowisko wykorzystuje \\ nowoczesne narzędzia inżynierskie: Arduino Mega 2560 oraz MATLAB/Simulink. Celem tego projektu \\ jest umożliwienie studentom wdrażania różnych systemów sterowania. Obejmuję to implementację \\ identyfikacji systemu, opracowanie algorytmów sterowania oraz przeprowadzenie weryfikacji \\ eksperymentalnej.
}




\section{Ewelina Chołodowicz}

\section{cholodowicz.ewelina@gmail.com}

Student at the Faculty of Electrical Engineering at West Pomeranian University of Technology Szczecin. Winner of the Mayor of Szczecin scientific scholarships for students $X I$ and XIV edition. Winner of the Ministry of Science and Higher Education scholarships in 2015/2016 and 2016/2017. Recent research topics are modeling, simulation and control of dynamic systems.

\section{Przemysław Orłowski, PhD, DSc}

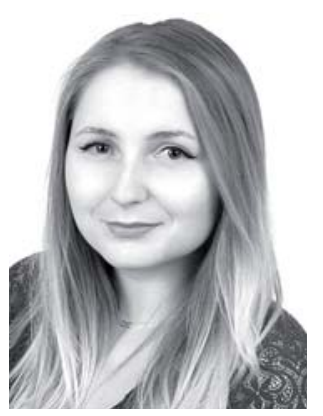

Associate Professor in the Department of Control and Measurements at West Pomeranian University of Technology Szczecin. The research topics are concerned on the analysis and synthesis of control systems, discrete-time systems, time-varying systems, nonlinear systems, uncertain systems and hybrid systems.

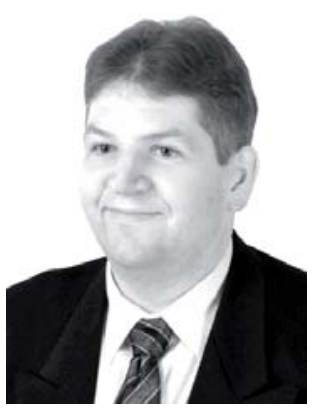

